\title{
Sessão Comemorativa do Sesquicentenário de Fundação dos Cursos Jurídicos no Brasil.
}

\section{A Redação}

Significativo programa marcou as festividades comemorativas da Fundação dos Cursos Jurídicos no Brasil, nesta Faculdade, desenvolvendo-se durante o ano todo, de 11 de agosto de 1976 a igual data de 1977, quando se encerraram solenemente.

Pela manhã, no saguão das Arcadas, emitiu-se o selo do Sesquicentenário, com o fac-símile da Lei de 11 de agosto de 1827, que instituiu os Cursos Jurídicos no Brasil, e com a efígie de D. Pedro I que a sancionou.

À noite, no salão nobre, às 21 horas, instalava-se a sessão solene da Congregação, com a participação de preclaros oradores e poetas, da Orquestra Sinfônica da USP e do Coral XI de Agosto.

Estiveram presentes, ou fizeram-se representar, altas personalidades políticas, do mundo jurídico e universitário, além do Magnífico Reitor da USP, em exercício, Professor Dr. Josué Camargo Mendes, dos professores da Congregação, estudantes, funcionários e centenas de convidados.

Presidiu à sessão o Diretor da Faculdade, Professor Dr. Ruy Barbosa Nogueira, que transmite a presidência dos trabalhos ao Magnífico Reitor. Sua Magnificência alude rapidamente às razões da solenidäde e devolve a direção ao Professor Ruy Barbosa Nogueira, que, após a execução do Hino Nacional pela Banda de Música da Polícia Militar do Estado de São Paulo, dá a palavra ao primeiro orador, Caio Marcelo de Carvalho Gianini, presidente do Centro Acadêmico XI de Agosto, representando o corpo discente. 
O representante dos estudantes, em exaltado discurso, situa a Faculdade no movimento político atual e conclama colegas, professores e todos os brasileiros a lutar pela reimplantação da democracia no Brasil.

Após as palavras do presidente do Centro Acadêmico, o poeta e membro da Academia Paulista de Letras, Paulo Bomfim, faz verdadeiro ato de fé na mocidade das Arcadas e em suas tradições de defensora da liberdade e da Justiça, através da poesia Creio em Ti, ó Faculdade!

A platéia vibra e aplaude os versos de Paulo Bomfim; ouve, a seguir, a oração do representante dos antigos alunos, desembargador presidente do Tribunal de Justiça de São Paulo, Dr. Gentil do Carmo Pinto, que em curta e densa oração, quase versos, compara a Faculdade à Catedral do Direito, focalizando pontos comuns, e evocando a ação acadêmica nos movimentos de libertação nacional.

Logo após, Pedro Oliveira Ribeiro Neto, membro da Academia Paulista de Letras, um dos maiores apologistas das glórias acadêmicas, redivive suas façanhas históricas em prol da liberdade e da Justiça, na poesia A Voz das Arcadas.

Antes de encerrar a primeira parte da sessão, o presidente da mesa dá a palavra ao representante do governo do Estado, Dr. Manoel Gonçalves Ferreira Filho, professor de Direito Constitucional e Vice-Governador do Estado. Sua Excelência associa-se às homenagens prestadas, em nome do governo, que reconhece o justo orgulho de São Paulo pela sua Academia, líder dos grandes movimentos políticos nacionais. Em seu discurso, exalta a necessidade de luta da Faculdade em favor de uma "Democracia Possível" para o Brasil, adaptada à realidade nacional, para que se perpetue a glória presente.

Em seguida, o diretor da Faculdade refere-se às comemorações que se realizaram durante todo o ano, constantes de conferências, congressos, exposições artísticas, filmagens, peças teatrais, concertos musicais, saraus, cursos de extensão universitária, projetando a Faculdade na história, na arte e, sobretudo, no Direito. Refere-se, também, à Faculdade atual, com seus Departamentos, vários ciclos de estudos e novos serviços criados a favor dos estudantes e do ensino jurídico.

Devolve, então, a palavra ao Magnífico Reitor que, relembrando vultos notáveis das Arcadas, enaltece as tradições como parte de inexcedível valor em seu acervo. Encerra a sessão 
e convida a todos para assistir à segunda parte do programa que constou de execução musical de peças de autores brasileiros, pela Orquestra de Câmara da Universidade de São Paulo, regida pelo Maestro Camargo Guarnieri, e pelo Coral XI de Agosto regido pelo Maestro, Jonas Cristenses.

Nota da Redação: As poesias dedicadas à Faculdade e declamadas na ocasião e na abertura dos festejos, em 11 de agosto de 1976, são publicadas a seguir; e os discursos na seção pertinente deste fascículo. 